\title{
Pengaruh Penambahan Abu Cangkang Kelapa Sawit pada Tanah Lempung dengan Uji Direct Shear
}

\author{
Christy Agata Makupiola ${ }^{* 1}$, Rais Rachman ${ }^{* 2}$, Irwan Lie Keng Wong ${ }^{* 3}$ \\ *1 Mahasiswa Program Studi Teknik Sipil, Universitas Kristen Indonesia Paulus, Makassar, Indonesia \\ makupiolachristy@gmail.com \\ *2,3 Dosen Program Studi Teknik Sipil, Universitas Kristen Indonesia Paulus, Makassar, Indonesia \\ rais.rachman@gmail.com dan irwanliekengwong@gmail.com
}

\begin{abstract}
ABSTRAK
Tujuan dari penelitian untuk menganalisis hasil sifat fisik tanah lempung yang digunakan dan menganalisis pengaruh penambahan abu cangkang kelapa sawit pada tanah lempung terhadap uji geser langsung (direct shear test). Dari hasil pengujian sifat fisis tanah, sampel tanah yang berasal dari jalan Yusuf Bauty, Kecamatan. Somba Opu, Kabupaten Gowa merupakan tanah lempung organic dengan sifat plastisitas sedang, menurut sistem klasifikasi tanah USCS maka tanah termasuk berbutir halus kelompok OH (lempung organic dengan plastisitas sedang dan munurut system AASTHO sampel tanah termasuk A-7-5.Dari penngujian Geser Langsung (Direct Shear Test) dengan penambahan abu cangkang kelapa sawit dari ketiga sampel dapat dilihat bahwa abu cangkang kelapa sawit mampu meningkatkan kohesi (c) pada setiap presentase penambahan abu cangkang kelapa sawit, namun pada sudut geseer terjadi penambahan yang tidak menentu pada setiap presentase penambahan abu cangkang kelapa sawit, hal ini di sebabkan karena abu cangkang kelapa sawit hanya mempunyai tegangan tarik sebagai bahan pengikat. Dari hasil penelitian yang dilakukan, penambahan abu cangkang kelapa sawit berpengaruh terhadap kuat geser hal ini menunjukan bahwa abu cangkang kelapa sawit dapat digunakan untuk bahan stabilisasi,
\end{abstract}

Kata kunci : Kelapa sawit, tanah lempung, direct shear.

\section{ABSTRACT}

The purpose of the study was to analyze the results of the physical properties of the clay used and to analyze the effect of adding oil palm shell ash to the clay on the direct shear test. From the results of testing the physical properties of the soil, the soil samples came from Jalan Yusuf Bauty, District. Somba Opu, Gowa Regency is an organic clay soil with moderate plasticity, according to the USCS soil classification system, the soil is classified as fine-grained $\mathrm{OH}$ group (organic clay with moderate plasticity and according to the AASTHO system the soil sample includes A-7-5. Direct Shear Test) with the addition of oil palm shell ash from the three samples, it can be seen that oil palm shell ash is able to increase cohesion (c) at each percentage addition of oil palm shell ash, but at the shear angle there is an erratic addition at each percentage addition of shell ash. palm oil, this is because oil palm shell ash only has tensile stress as a binder. From the results of research conducted, the addition of oil palm shell ash has an effect on shear strength, this shows that oil palm shell ash can be used for stabilization,

Keywords: Oil palm, clay soil, direct shear.

\section{PENDAHULUAN}

Perusahaan perkebunan kelapa sawit PT Unggul Widya Teknologi Lestari, beroperasi di Kecamatan Baras, Kabupaten Mamuju Utara, Sulawesi Barat saat ini mampu mengolah sebanyak 2100 ton sawit per hari, masing-masing
900 ton di pabrik lama dan 1.200 ton di pabrik barunya [1]. Di mana dari proses pengolahan menghasilkan 21\% minyak kelapa sawit mentah (Crude Palm Oil/CPO), 5\% kernel, dan 6\% cangkang.

Saat itu, kelapa sawit yang dikembangkan di tiga kabupaten, yakni Mamuju, Mamuju Tengah, dan 
Paulus Civil Engineering Journal

Jurnal Teknik Sipil UKI-Paulus Makassar https://doi.org/10.52722/pcej.v3i2.3218

Pasangkayu, ini mulai menjadi penggerak dan penopang ekonomi di Sulbar dan membuka lapangan kerja baru. Data Dinas Perkebunan Sulbar, hingga tahun 2018 jumlah perusahaan kelapa sawit mencapai 17 perusahaan dengan luasan lahan perkebunan yaitu 79 ribu hektare.

Limbah abu cangkang kelapa sawit merupakan limbah hasil pengelohan kelapa sawit yang telah dibakar dalam tungku pembakaran dengan suhu $700^{\circ} \mathrm{C}-800^{\circ} \mathrm{C}$. Abu cangkang kelapa sawit memiliki sifat pozzolanic karena mengandung silica dan alumina yang dapat membentuk bahan semen yang bermanfaat pada proses stabilitas tanah karena bisa meningkatkan daya ikat antar partikel tanah [2]. Untuk mengetahui karakteristik campuran tanah dengan abu cangkang kelapa sawit maka dilakukan uji direct shear atau uji geser langsung

Tanah lempung (clays) umumnya merupakan fraksi submikroskopis dan mikroskopis berbentuk lempeng pipih berupa partikel darai mika, mineral lempung dan mineral yang halus [3]. Belum tentu tanah dengan ukuran partikel lempung tersebut juga mengandung mineral-mineral lempung.

Dari segi material tanah lempung dan mineral yang mempunyai partikel mineral tertentu yang dapat menghasilkan sifat-sifat plastis pada tanah jika dicampur dengan air. Sedangkan dari segi ukuran partikel tersebut berukuran lebih kecil dari 2 mikron atau < 5 mikron. Partikel mineral lempung umumnya berukuran kloid $(<1 \mu)$ dan ukuran $2 \mu[4]$

Kuat geser tanah mmerupakan kemampuan tanah melawan geser yang terjadi pada tanah pada saat terbeban. Teori Mohr keruntuhan suatu bahan dapat terjadi oleh akibat adanya kombinasi bahan kritis dari tegangan normal dan tegangan geser. Kuat geser tanah adalah gaya perlawanan yang dilakukan oleh butir-butir tanah terhadap desakan atau tarikan [5] [6].

Alat uji geser terdiri dari sebuat kotak logam berisi sampel tanah yang selanjutnya akan diuji. Ukuran sampel tanah umum digunakan sekitar 3 sampai 4 inchi $(1935,48$ sampai $2580,64 \mathrm{~mm} 2)$ luas penampang dan tingginya 1 inchi $(25,4 \mathrm{~mm})$. Gaya normal pada sampel tanah sampai $150 \mathrm{psi}$ $(1034,2 \mathrm{kN} / \mathrm{m} 2)$ [7].
Volume 3 No.2, Juni 2021

e-ISSN 2775-4529

p-ISSN 2775-8613
Ada dua sistem klasifikasi yang bisa dipakai dalam bidang teknik yaitu sistem klasifkasi Unified dan AASHTO. Klasifikasi Unified (USCS) sistem ini disempurnakan oleh kelompok teknisi USBR (United State Berau of Reclamationl). Sistem klasifikasi AASTHO dikembangkan pada tahun 1929 sebagai Public Road Administration Classification System. Sistem ini diajukan oleh Commottee on Classification of Materials for Subgrade and Granular Type of Highway Research Board pada tahun 1945 (ASTM standard No. D3282, AASHTO mode M 145).

Sistem klasifikasi ini didasarkan pada ukuran, kerikil : tanah lolos ayakan diameter $75 \mathrm{~mm}$ (3 in) yang tertahan pada ayakan No.200 (2 mm). Pasir : tanah yang lolos ayakan No.10 $(2 \mathrm{~mm})$ dan yang tertahan pada ayakan No. $200(0,075 \mathrm{~mm})$ [8]. Lanau dan lempung : tanah lolos ayakan No.200. Apabila batuan (ukuran lebih besar dari $75 \mathrm{~mm}$ ) ditemukan di dalam contoh tanah yang akan ditentukan klasifikasi tanahnya maka batuan terbut harus dikeluarkan terlebih dahulu [8]

Peneliti sebelumnya yang meneliti tentang stabilitas tanah lempung antara lain Jupriah yang meneliti pengaruh penambahan abu cangkang kelapa sawit guna meningkatkan stabilitas tanah lempung [7]. Stabilitas tanah lempung dengan menggunakan abu cangkang kelapa sawit terhadap nilai kuat tekan bebas (studi khusus jalan desa cibeulah pandeglang) [9]. Stabilitas tanah lempung dengan bahan tambah abu cangkang kelapa sawit di tinjau dari kuat geser tanah (direct shear) [10] . Pengaruh Penambahan Limbah Abu Cangkang Sawit (POFA) Terhadap Nilai California Bearing Ratio (CBR) untuk Stabilisasi Tanah Lempung [7]

Tujuan dari penelitian untuk menganalisis hasil sifat fisik tanah lempung yang digunakan dan menganalisis pengaruh penambahan abu cangkang kelapa sawit pada tanah lempung terhadap uji geser langsung (direct shear test)

\section{METODE PENELITIAN}

\section{Lokasi Penelitian}

Lokasi pengambilan sampel tanah lempung pada, Kecamatan Somba Opu, Kabupaten Gowa, sedangkan pengambilan sampel limbah kelapa sawit pada Kecamatan Baras, Kabupaten Mamuju Utara, Sulawesi Barat seperti pada Gambar 1. 


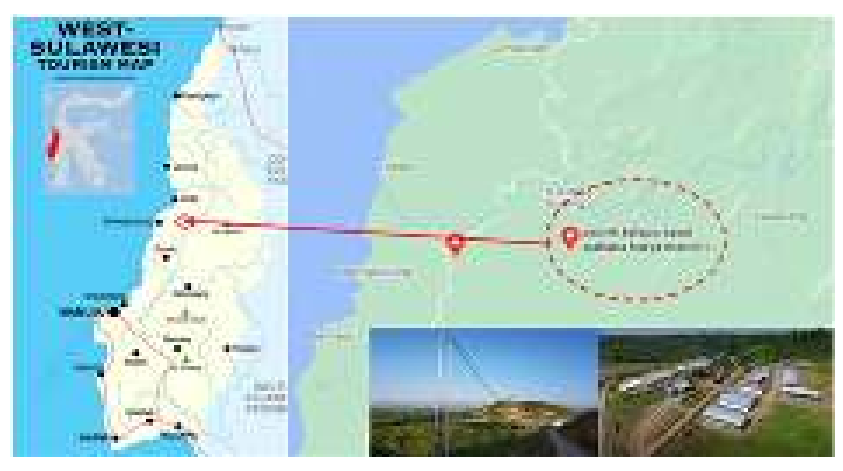

Gambar 1. Lokasi pengambilan kelapa sawit

\section{Pemeriksaan Karakteristik Tanah}

Pemeriksaan karakteristik tanah dilakukan pengujian kadar air (ASTM 2216) Pemeriksaan Berat Jenis (ASTM 854). Pemeriksaan batasbatas Atterberg (ASTM 4318-95). Pengujian Gradasi butiran (ASTMD 422-63) dan (ASTM 1140-54)

3. Pengujian Geser Langsung (direct shear) Pengujian geser langsung atau direct shear menentukan besarnya kuat tekan geser tanah yang terdiri dari sudut geser dan kohesi dengan alat uji geser langsung pada kondisi consolidated drainer. Pengujian geser langsung berdarkan ASTM 2166-68.

\section{ANALISIS DAN PEMBAHASAN}

\section{Hasil Pengujian Sifat Fisis Tanah}

Pengujian karakteristik tanah untuk mengetahui sifat fisis tanah agar dapat mengetahui jenis tanah tersebut melalui standar spesifikasi. Sampel tanah yang disiapkan adalah tanah kondisi tanah rusak yang mengalami penurunan yang berasal dari Kabupaten Gowa. Semua sampel tanah yang telah disiapkan kemudian dilakukan pengujian sifat fisis tanah yang dilaksanakan di Laboratorium Mekanika Tanah, Fakultas Teknik Universitas Kristen Indonesia Paulus. Dari hasil pengujian sifat fisis tanah yang dilakukan didapatkan hasil masingmasing tiap percobaan pada Tabel 1. sebagai berikut :

Tabel 1. Rekapitulasi Pengujian Sifat Fisis Tanah Sampel Tanah

\begin{tabular}{|c|c|c|c|c|c|c|}
\hline \multirow{2}{*}{ No } & \multirow{2}{*}{\multicolumn{3}{|c|}{ Uji Laboratorium }} & \multicolumn{3}{|c|}{ Sampel } \\
\hline & & & & \multirow{2}{*}{$\frac{1}{35,317}$} & \multirow{2}{*}{$\frac{\text { II }}{33,119}$} & \multirow{2}{*}{$\frac{\text { III }}{35,887}$} \\
\hline 1 & & dar air & (w) \% & & & \\
\hline 2 & & t Jenis & (Gs) & 2,59 & 2,59 & 2,622 \\
\hline \multirow{4}{*}{3} & \multirow{4}{*}{ 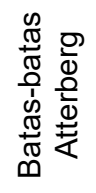 } & Batas Cair & (Liquid Limit) , \% & 48,30 & 54,03 & 54,20 \\
\hline & & Batas Plastis & (Plastic Limit), \% & 34,26 & 40,63 & 40,53 \\
\hline & & Batas Susut & (Shrinkage Limit), \% & 6,11 & 8,60 & 8,52 \\
\hline & & Indeks Pla & (Plasticity Index), \% & 14,04 & 13,60 & 13,60 \\
\hline & & Persen & Saringan No. $200 \%$ & 92,615 & 92,518 & 92,518 \\
\hline \multirow{4}{*}{4} & \multirow{4}{*}{ 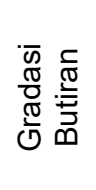 } & Gravel & G \% & 0 & 0 & 0 \\
\hline & & Sand & S \% & 7,385 & 7,49 & 5,667 \\
\hline & & Silt & $\mathrm{M} \%$ & 71,979 & 79,379 & 84,953 \\
\hline & & Clay & C \% & 20,635 & 13,131 & 9,379 \\
\hline
\end{tabular}

dari Tabel 1 pengujian kadar air tanah asli diperoleh nilai kadar air yang terkandung pada sampel I sebesar $35,317 \%$, sampel II sebesar $33,119 \%$ dan sampel III $35,887 \%$. Pengujian berat jenis tersebut didapatkan nilai berat jenis tanah pada sampel I yaitu 2,59, sampel II yaitu 2,59, dan sampel III yaitu 2,62. Pengujian batas-batas atterberg pada sampel tanah asli yang telah diteliti di laboratorium mekanika tanah pada pengujian batas cair, batas plastis dan batas susut dapat dilihat pada Tabel 2 berikut ini 
Tabel 2. Pengujian batas-batass atterberg

\begin{tabular}{cccc}
\hline & LL & PL & IP \\
\hline Tanah Asli 1 & 48,30 & 34,26 & 14,04 \\
Tanah Asli 2 & 54,03 & 40,63 & 13,40 \\
Tanah Asli 3 & 54,20 & 40,53 & 13.67 \\
\hline Rata-rata & 52,176 & 38,473 & 13,703 \\
\hline
\end{tabular}

\section{Pengujian Analisa saringan (ASTM 422-} 63) dan Hydrometer (ASTM D1682-90)

Hasil pengujian yang diperoleh dari perhitungan Analisa saringan yaitu nilai persen lolos titap-tiap saringan yang kemudian dihubungkan dengan diameter saringan sehingga terbentuk sebuah garis yang menandakan bahwa sekian persen tanah berpasir yang diperoleh. Setelah itu, pada Analisa Hydometer, diperoleh diameter butir daripada tanah dan presentase kehalusannya. Kedua hal tersebut lalu dihubungkan pada titik koordinat tiap diameter saringan kemudian menghasilkan bahwa sekian persen tanah yang tergolong lanau dan lempung. Perolehan tanah berpasir, berlanau, dan berlempung bila dari grafik (terlampir), yaitu :

\section{Sampel 1 :}

1) Pasir = $100-\%$ lewat saringan no. 200

$=100 \%-92,615 \%=7,385 \%$

2) Lanau = \% lewat saringan no. $200-N^{\prime}$

$=92,615 \%-20,635=71,979 \%$

3) Lempung $=100-($ Pasir - Lanau $)$

$=100 \%-(7,385 \%+71,979 \%)$

$=20,636 \%$

\section{Sampel 2 :}

1) Pasir = $100-\%$ lewat saringan no.200

$=100 \%-92,518 \%=7,49 \%$

2) Lanau = \% lewat saringan no. $200-\mathrm{N}^{\prime}$

$=92,518 \%-13,1314=79,379 \%$

3) Lempung $=100-($ Pasir - Lanau $)$

$=100 \%-(7,49 \%+79,379 \%)$

$=13,131 \%$

\section{Sampel 3 :}

1) Pasir = $100-\%$ lewat saringan no. 200

$$
=100 \%-94,333 \%=5,667 \%
$$

2) Lanau = \% lewat saringan no. $200-N^{\prime}$

$$
=94,333 \%-9,3796=84,953 \%
$$

3) Lempung $=100-($ Pasir - Lanau $)$

$$
\begin{aligned}
& =100 \%-(5,667 \%+84,953 \%) \\
& =9,38 \%
\end{aligned}
$$

\section{Hasil Pengujian Geser Langsung (Direct shear test)}

Dari hasil pengujian uji geser langsung dapat dilihat nilai kohesi dan sudut geser yang diperoleh pada tiap-tiap persen penambahan serabut kelapa sebagai berikut :

Tabel 3. Kohesi dan Sudut Geser titik 1

\begin{tabular}{ccc}
\hline $\begin{array}{c}\text { Variasi abu cangkang } \\
\text { kelapa sawit }(\%)\end{array}$ & $\begin{array}{c}\text { Kohesi } \\
\left(\mathrm{kg} / \mathrm{cm}^{2}\right)\end{array}$ & $\begin{array}{c}\text { sudut } \\
\text { geser (o) }\end{array}$ \\
\hline 0 & 0.049 & 9 \\
3 & 0.053 & 10 \\
6 & 0.056 & 11 \\
9 & 0.066 & 14 \\
\hline
\end{tabular}

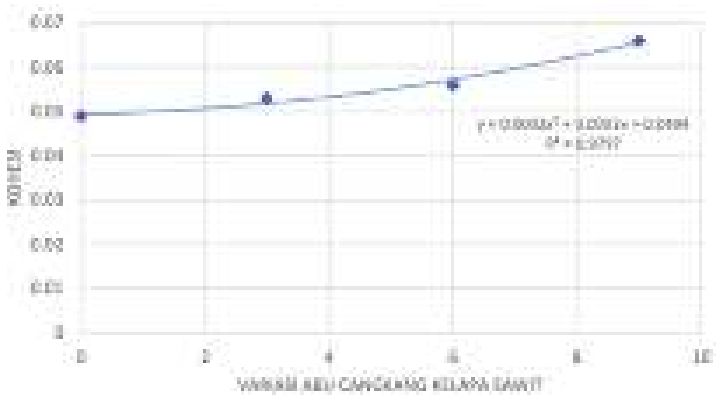

Gambar 2. Hubungan Kohesi (c) dengan kadar abu cangkang kelapa sawit titik 1 


\section{Paulus Civil Engineering Journal}

Jurnal Teknik Sipil UKI-Paulus Makassar

https://doi.org/10.52722/pcej.v3i2.3218

Dari Gambar 2 dapat dilihat kenaikan kohesi pada setiap penambahan abu cangkang kelapa sawit di mana variasi $0 \%$ sebesar $0,049 \mathrm{~kg} / \mathrm{cm} 2$, variasi $3 \%$ sebesar $0,053 \mathrm{~kg} / \mathrm{cm} 2$, variasi $6 \%$ sebesar $0,056 \mathrm{~kg} / \mathrm{cm} 2$, dan variasi $9 \%$ sebesar 0,066 $\mathrm{kg} / \mathrm{cm} 2$

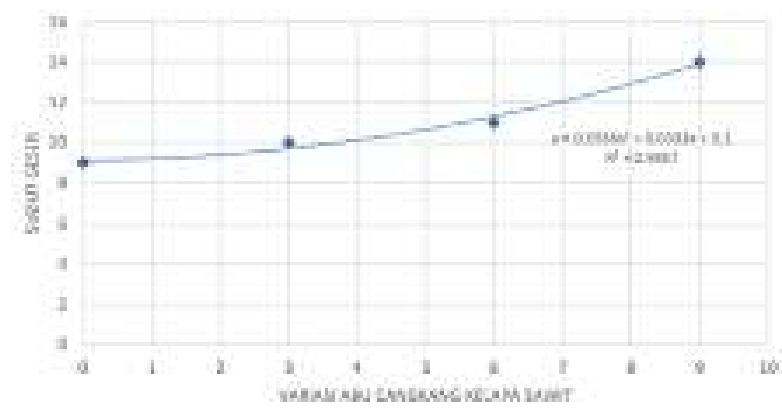

Gambar 3.. Hubungan sudut geser $\left(^{\circ}\right)$ dengan abu cangkang kelapa sawit titik 1

Dari Gambar 3 dapat dilihat kenaikan kohesi pada setiap penambahan abu cangkang kelapa sawit di mana variasi $0 \%$ sebesar $0,063 \mathrm{~kg} / \mathrm{cm} 2$, variasi $3 \%$ sebesar $0,067 \mathrm{~kg} / \mathrm{cm} 2$, variasi $6 \%$ sebesar $0,079 \mathrm{~kg} / \mathrm{cm} 2$ dan variasi $9 \%$ sebesar 0,085 $\mathrm{kg} / \mathrm{cm} 2$

Tabel 4. Kohesi dan sudut geser titik 2

\begin{tabular}{ccc}
\hline $\begin{array}{c}\text { Variasi abu cangkang } \\
\text { kelapa sawit }(\%)\end{array}$ & $\begin{array}{c}\text { Kohesi } \\
\left(\mathrm{kg} / \mathrm{cm}^{2}\right)\end{array}$ & $\begin{array}{c}\text { sudut } \\
\text { geser }(\mathrm{o})\end{array}$ \\
\hline 0 & 0.063 & 10 \\
3 & 0.067 & 10 \\
6 & 0.079 & 11 \\
9 & 0.085 & 12 \\
\hline
\end{tabular}

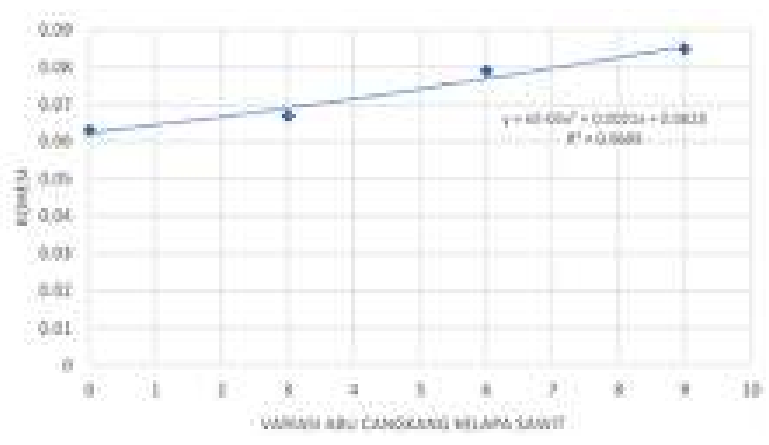

Gambar 4. Hubungan Kohesi (c) dengan kadar abu cangkang kelapa sawit titik 2

Dari Gambar 4 dapat dilihat kenaikan kohesi pada setiap penambahan abu cangkang kelapa sawit di mana variasi $0 \%$ sebesar $0,063 \mathrm{~kg} / \mathrm{cm} 2$, variasi
$3 \%$ sebesar $0,067 \mathrm{~kg} / \mathrm{cm} 2$, variasi $6 \%$ sebesar $0,079 \mathrm{~kg} / \mathrm{cm} 2$ dan variasi $9 \%$ sebesar 0,085 $\mathrm{kg} / \mathrm{cm} 2$

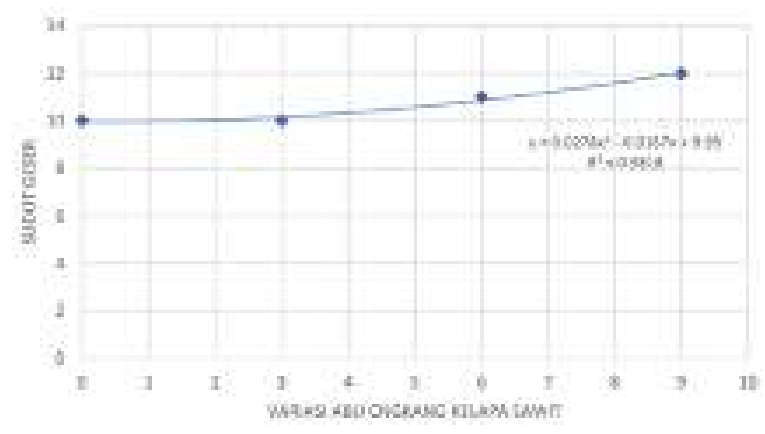

Gambar 5. Hubungan sudut geser (o) dengan kadar abu cangkang kelapa sawit titik 2

Dari Gambar 5 dapat dilihat bahwa pada variasi $0 \%$ dan 3\% tidak mengalami kenaikan, pada variasi $6 \%$ dan $9 \%$ mengalai kenaikan sebesar 10.

Tabel 5. Kohesi dan sudut geser titik 3

\begin{tabular}{ccc}
\hline $\begin{array}{c}\text { Variasi abu cangkang } \\
\text { kelapa sawit }(\%)\end{array}$ & $\begin{array}{c}\text { Kohesi } \\
\left(\mathrm{kg} / \mathrm{cm}^{2}\right)\end{array}$ & $\begin{array}{c}\text { sudut } \\
\text { geser (o) }\end{array}$ \\
\hline 0 & 0.077 & 8 \\
3 & 0.083 & 9 \\
6 & 0.091 & 10 \\
9 & 0.099 & 10 \\
\hline
\end{tabular}

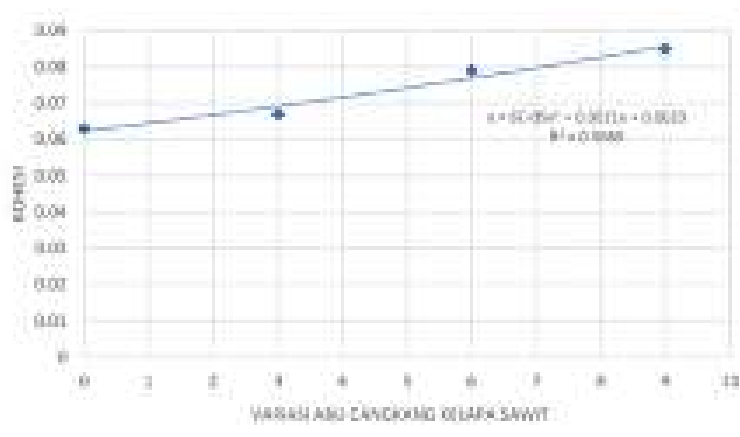

Gambar 6. Hubungan kohesi (c) dengan kadar abu cangkang kelapa sawit titik 3

Dari Gambar 6 dapat dilihat kenaikan kohesi pada setiap penambahaan abu cangkang kelapa sawit di mana pada variasi $0 \%$ sebesar $0,077 \mathrm{~kg} / \mathrm{cm} 2$, variasi $3 \%$ sebesar $0,083 \mathrm{~kg} / \mathrm{cm} 2$, variasi $6 \%$ sebesar $0,091 \mathrm{~kg} / \mathrm{cm} 2$ dan variasi $9 \%$ sebesr $0,099 \mathrm{~kg} / \mathrm{cm} 2$. 


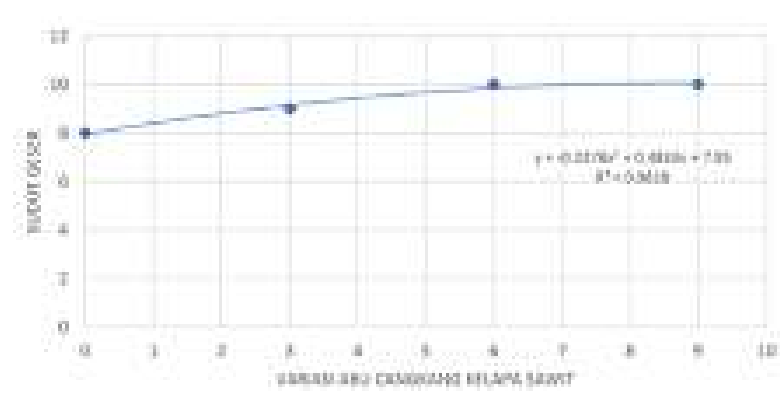

Gambar 7. Hubungan kohesi (c) dengan kadar abu cangkang kelapa sawit titik 3

\section{Pembahasan Hasil Analisis}

1. Pengujian Sifat Fisis Tanah

Berdasarkan Tabel 5 di atas menujukkan :

a. Berdasarkan berat jenis (Gs)

Nilai rata-rata dari 3 titik pengujian berat jenis (Gs) sampel tanah dari Jalan Yusuf Bauty, Kecamatan Somba Opu, Kabupaten Gowa diperoleh hasil berat jenis tanah (Gs) sebesar 2,60, Tabel 3 klasifikasi berdasarkan berat jenis (Gs) menunjukan bahwa tanah ini termasuk tanah lempung organik,

Tabel 6. Rekapitulasi rata-rata hasil pengujian sifat fisis tanah dari 3 titik

\begin{tabular}{|c|c|c|c|c|}
\hline No & \multicolumn{3}{|c|}{ Uji Sampel } & Nilai Rata-rata \\
\hline 1 & Kadar air & \multicolumn{2}{|c|}{ (w) \% } & 34,774 \\
\hline 2 & Berat enis & \multicolumn{2}{|c|}{ (Gs) } & 2,602 \\
\hline \multirow{4}{*}{3} & \multirow{4}{*}{$\begin{array}{c}\text { Batas-batas } \\
\text { Atterberg }\end{array}$} & Batas Cair & (Liquid Limit) , \% & 52,18 \\
\hline & & Batas Plastis & (Plastic Limit), \% & 38,47 \\
\hline & & Batas Susut & (Shrinkage Limit), \% & 7,74 \\
\hline & & \multicolumn{2}{|c|}{ Indeks Plastisitas (Plasticity Index), \% } & 13,70 \\
\hline \multirow{5}{*}{4} & \multirow{5}{*}{ Gradasi } & \multicolumn{2}{|c|}{ Persen Lolos Saringan No. 200 \% } & 93,15 \\
\hline & & Gravel & G \% & 0 \\
\hline & & Sand & $\mathrm{S} \%$ & 6,847 \\
\hline & & Silt & $M \%$ & 78,77 \\
\hline & & Clay & $\mathrm{C} \%$ & 14,38 \\
\hline
\end{tabular}

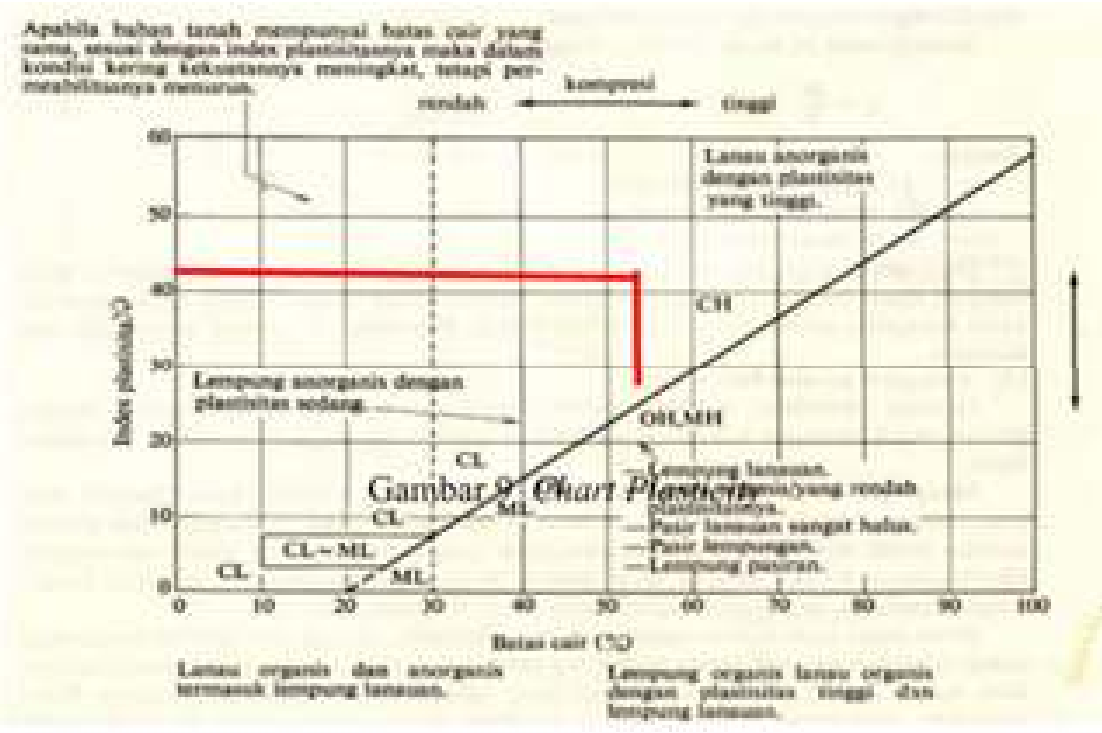


Paulus Civil Engineering Journal

Jurnal Teknik Sipil UKI-Paulus Makassar https://doi.org/10.52722/pcej.v3i2.3218

\section{b. Klasifikasi tanah menurut USCS}

Pengujian batas-batas Atterberg yang terdiri dari $P L=38,47 \%$, $L L=52,18 \%$, dan $\mathrm{IP}=13,70 \%$. Pengujian gradasi Analisa saringan dan Hidrometer, dimana persen lolos saringan No.200 sebesar $93,15 \%$.

Berdasarkan data di atas maka dapat diplot ke grafik chart plasticity

Hasil penginputan nilai LL vs PI menujukkan bahwa sampel tanah dapat diklasifikasikan sebagai tanah lempung organis dengan plastisitas sedang.

\section{c. Klasifikasi tanah menurut AASTHO}

Pengujian batas-batas Atterberg yang terdiri dari $\mathrm{PL}=38,47 \%$, $\mathrm{LL}=52,18 \%$, dan $\mathrm{IP}=13,70 \%$. Pengujian gradasi Analisa saringan dan Hidrometer, dimana persen lolos saringan No.200 sebesar $93,15 \%$.

Dari klasifikasi tanah menurut AASTHO menunjukkan sampel tanah tergolong A-7-5 dengan tipe material yang pokok umunya tanah berlempung.

\section{Pengujian Geser Langsung (Direct Shear Test)}

Tabel 7. Variasi abu cangkang kelapa sawit dan Kohesi (c) dari 3 titik.

\begin{tabular}{cccc}
\hline $\begin{array}{c}\text { Variasi abu cangkang } \\
\text { kelapa sawit }\end{array}$ & Titik I & Titik II & Titik III \\
\hline 0 & 0.049 & 0.063 & 0.077 \\
3 & 0.053 & 0.067 & 0.083 \\
6 & 0.056 & 0.079 & 0.091 \\
9 & 0.066 & 0.085 & 0.099 \\
\hline
\end{tabular}

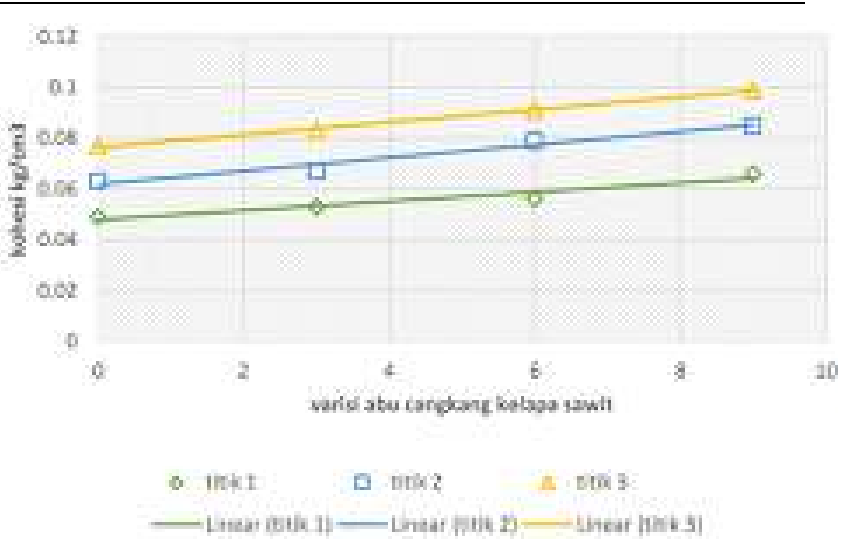

Gambar 8. Kohesi (c) vs kadar abu cangkang kelapa sawit
Volume 3 No.2, Juni 2021

e-ISSN 2775-4529

p-ISSN 2775-8613

Pengujian Geser Langsung (Direct ShearTest) dalam penambahan abu cangkang kelapa sawit pada Tabel 7 serta Gambar 8, presentase abu cangkang kelapa sawit dan kohesi pada titik I mengalami peningkatan, dimana pengujian geser langsung $0 \%$ mendapatkan kohesi sebesar 0,049 $\mathrm{kg} / \mathrm{cm} 2,3 \%$ sebesar $0,053 \mathrm{~kg} / \mathrm{cm} 2,6 \%$ sebesar $0,056 \mathrm{~kg} / \mathrm{cm} 2$, dan $9 \%$ sebesar $0,066 \mathrm{~kg} / \mathrm{cm} 2$. Pada titik II juga mengalami peningkatan, dimana pengujian geser langsung $0 \%$ sebesar 0,063 $\mathrm{kg} / \mathrm{cm} 2,3 \%$ sebesar $0,067 \mathrm{~kg} / \mathrm{cm} 2,6 \%$ sebesar $0,079 \mathrm{~kg} / \mathrm{cm} 2$ dan $9 \%$ sebesar $0,085 \mathrm{~kg} / \mathrm{cm} 2$. Di titik III juga mengalami peningkatan, dimana ppengujian geser langsung pada $0 \%$ mendapatkan nilai kohesi sebesar $0,077 \mathrm{~kg} / \mathrm{cm} 2$, $3 \%$ sebesar $0,083 \mathrm{~kg} / \mathrm{cm} 2,6 \%$ sebesar 0,091 $\mathrm{kg} / \mathrm{cm} 2$, dan $9 \%$ sebesar $0,099 \mathrm{~kg} / \mathrm{cm} 2$.

Tabel 8. Variasi abu cangkang kelapa dan sudut geser (o) dari 3 titik

\begin{tabular}{cccc}
\hline $\begin{array}{c}\text { Variasi abu cangkang } \\
\text { kelapa sawit }\end{array}$ & Titik I & Titik II & Titik III \\
\hline 0 & 9 & 10 & 8 \\
3 & 10 & 10 & 9 \\
6 & 11 & 11 & 10 \\
9 & 14 & 12 & 10 \\
\hline
\end{tabular}

Pengujian Geser langsung (Direct Shear Test) dengan penambahan abu cangkang kelapa sawit Tabel 8 serta Gambar 9, presentase abu cangkang kelapa sawit dan sudut geser pada titik I mengalami peninhkatan, dimana pengujian geser langsung pada $0 \%$ mendapatkan nilai sudut geser sebesar $9^{\circ}, 3 \%$ sebesar $10^{\circ}, 6 \%$ sebesar $11^{\circ}$ dan $9 \%$ sebesar $14^{\circ}$. sedangkan pada titik II mengalami peningkatan dimana pengujian geser langsung pada $0 \%$ mendapatkan nilai sudut geser sebesr $10^{\circ}, 3 \%$ sebesar $10^{\circ}, 6 \%$ sebesar $11^{\circ}$ dan $9 \%$ sebesar $12^{\circ}$. pada titik III juga mengalami peningkatan yang sama, dimana pengujian geser langsung pada $0 \%$ mendapatkan nilai sudut geser sebesar $8^{\circ}, 3 \%$ sebesar $9^{\circ}, 6 \%$ dan $9 \%$ sebesar $10^{\circ}$. 


\section{Paulus Civil Engineering Journal}

Jurnal Teknik Sipil UKI-Paulus Makassar https://doi.org/10.52722/pcej.v3i2.3218

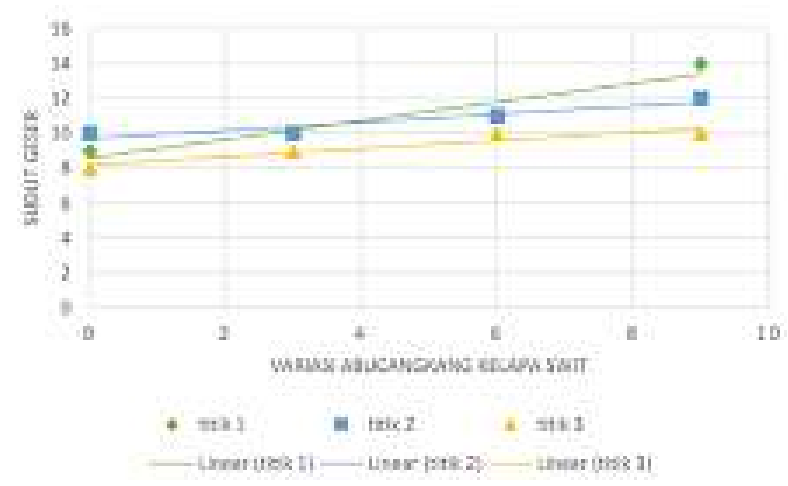

Gambar 9. Sudut geser $\left(^{\circ}\right)$ vs kadar abu cangkang kelapa sawit

Dari pengujian ini menunjukan bahwa masingmasing sampel tanah dengan campuran abu cangkang kelapa sawit dapat meningkatkan kohesi (c) dan sudut geser $\left(^{\circ}\right)$ dari setiap sampel karena abu cangkang kelapa sawit mempunyai tegangan tarik yang tinggi dan berfungsi sebagai bahan pengikat serta mudah meloloskan air, hal ini menjadikan kohesi (c) dan sudut geser $\left(^{\circ}\right)$ tanah meningkat.

Kohesi (c) dan sudut geser $\left({ }^{\circ}\right)$ merupakan nilai sudut geser tanah, semakin tinggi nilainya, maka kuat geser akan semakin tinggi, dari hasil pengujian dengan penambahan abu cangkang kelapa sawit akan meningkatkan kuat geser tanah.

\section{KESIMPULAN}

Berdasarkan hasil pengujian dan Analisa data diperoleh di Laboratorium maka dapat disimpulkan sebagai berikut :

1. Dari hasil pengujian sifat fisis tanah, sampel tanah yang berasal dari jalan Yusuf Bauty, Kecamatan. Somba Opu, Kabupaten Gowa merupakan tanah lempung organic dengan sifat plastisitas sedang, menurut sistem klasifikasi tanah USCS maka tanah termasuk berbutir halus kelompok $\mathrm{OH}$ (lempung organic dengan plastisitas sedang dan munurut system AASTHO sampel tanah termasuk A-7-5.

2. Dari penngujian Geser Langsung (Direct Shear Test) dengan penambahan abu cangkang kelapa sawit dari ketiga sampel dapat dilihat bahwa abu cangkang kelapa sawit mampu meningkatkan kohesi (c) pada setiap presentase penambahan abu
Volume 3 No.2, Juni 2021

e-ISSN 2775-4529

p-ISSN 2775-8613

cangkang kelapa sawit, namun pada sudut geseer terjadi penambahan yang tidak menentu pada setiap presentase penambahan abu cangkang kelapa sawit, hal ini di sebabkan karena abu cangkang kelapa sawit hanya mempunyai tegangan tarik sebagai bahan pengikat.

Dari hasil penelitian yang dilakukan, penambahan abu cangkang kelapa sawit berpengaruh terhadap kuat geser hal ini menunjukan bahwa abu cangkang kelapa sawit dapat digunakan untuk bahan stabilisasi,

\section{DAFTAR PUSATAKA}

[1] Daud, A. N. Musu, R. Rachman, dan B. Kusuma, "Immersion index HRS -WC HalpGap gradation with oil palm waste filler substitution," Medan, 2021, vol. 1088, hlm. 110. doi: 10.1088/1757-899X/1088/1/012087.

[2] L. B. Suparma, T. W. Panggabean, dan S. Mude, "Potensi Penggunaan Limbah Kelapa Sawit Sebagai Agregat Pengisi Pada Campuran Hot Rolled Sheet-Base," Jurnal Transportasi, vol. 14, no. 22, hlm. 87-96, 2014.

[3] H. C. Hardiyatmo, Mekanika Tanah I, 7 ed. Yogyakarta: Gajah Mada University Press, 2019.

[4] R. A. Chandra, "Kajian Kuat Desak Dan Modulus Elastisitas Beton Dengan Penambahan Abu Bonggol Jagung Sebagai Zat Additive," Skripsi, Program Studi Teknik Sipil Fakultas Teknik Universitas Atma Jaya Yogyakarta, Yogyakarta, 2013.

[5] J. E. Bowles dan J. K. Hainim, Sifat-sifat Fisis dan Geoteknis Tanah, 2 ed. Jakarta Indonesia: Erlangga, 2008.

[6] G. K. Bumbungan, J. Patanduk, dan I. L. K. Wong, "Pengaruh Penambahan Abu Batubara Terhadap Hasil Uji Kompaksi (Studi Kasus Tanah Lempung Toraja Utara)," Paulus Civil Engineering Journal, vol. 3, no. 2, hlm. 180-186, 2020.

[7] H. Diah, Y. Apriyanti, dan F. Fahriani, "Pengaruh Penambahan Limbah Abu Cangkang Sawit (POFA) Terhadap Nilai California Bearing Ratio (CBR) untuk Stabilisasi Tanah Lempung," Fropil, vol. 8, no. 2, hlm. 102-109, 2020, doi: https://doi.org/10.33019/fropil.v8i2.2143. 
[8] D. M. Pangadongan, R. Rachman, dan I. L. K. Wong, "Pengaruh Penambahan Bubuk Gypsum Pada Tanah Lempung Terhadap Uji California Bearing Ratio (CBR)," Paulus Civil Engineering Journal, vol. 2, no. 4, hlm. 263272, 2020.

[9] R. I. Kusuma, E. Mina, dan R. Bonar, "Stabilisasi Tanah Lempung dengan Menggunakan Abu Sawit Terhadap Nilai Kuat
Tekan Bebas (Studi Kasus Jalan Desa Cibeulah, Pandeglang)," Jurnal Fondasi, vol. 4, no. 2, hlm. 69-80, 2015.

[10] J. Sarifah dan B. Pasaribu, "Pengaruh Penggunaan Abu Cangkang Kelapa Sawit Guna Meningkatkan Stabilitas Tanah Lempung," Buletin Utama Teknik, vol. 13, no. $1,2015$. 